\title{
Recent patent applications in gene expression
}

\begin{tabular}{ll} 
Patent \# & Subject \\
\hline US 20050227326 & $\begin{array}{l}\text { A method of producing a recombinant protein in a yeast } \\
\text { cell, comprising obtaining a vector into which a gene } \\
\text { encoding the target protein has been inserted, where } \\
\text { the modification results in a significant reduction in } \\
\text { gene expression. }\end{array}$ \\
\hline US 20050221293 & $\begin{array}{l}\text { A novel isolated single-stranded DNA virus microRNA } \\
\text { molecule comprising moieties having contiguous bases } \\
\text { bonded to backbone units, on a molecular backbone } \\
\text { having backbone units; useful for controlling gene } \\
\text { expression in organisms. }\end{array}$
\end{tabular}

WO 200590562 A novel, moderately low-temperature, transcriptional-

US 20050214823 A probe array comprising specified nucleic acid probes;

US 20050214309 A method for modulating transcription factor-mediated

WO 200588513 A method for classifying a test tissue sample involving

US 20050203709 A method of correcting errors in pair(s) of gene expression

JP 2005245310 A method for real-time PCR gene expression analysis

WO 200581635 A method for analyzing large-scale, multidimensional

WO $200583429 \quad$ Use of gene expression profiles of patient biological

US 20050196764 A method for detecting expression of a gene in a blood WO 200580546 A sensor device for detecting an analyte in a sample,
comprising a sample, a first permeable polymeric hydrogel regulation element comprising a defined nucleotide sequence that is capable of promoting gene expression; useful for producing proteins by recombinant DNA techniques. useful for measuring gene expression of different multiple mature isoforms of RNA from mouse genes. gene expression by exposing the transcription factor to an inhibitory agent that binds to a linker domain of the transcription factor; useful for treating neoplasia. calculating the extent of dissimilarity between a gene expression vector and a gene expression matrix using algebraic expressions involving the eigenvector of the covariance matrix; useful for diagnosing genetic diseases. profiles, such as reducing inter-slide variations and improving measurement precision, accuracy, sensitivity and specificity, by adjusting the experimental profile to generate an error-adjusted experiment profile. using a fluorescent material having a hydroxyl group, preferably 5 -and/or 6-carboxy-X-rhodamine, as a passive internal reference; useful for the typing of single nucleotide polymorphisms, and food analysis. data, e.g., gene expression data, involving performing unsupervised analysis of data according to a distance matrix reordered using a weighting function. samples for assessing breast cancer, staging breast cancer, determining breast cancer patient protocol, or treating breast cancer. sample involving detecting the presence of RNA, CDNA or an expressed sequence tag complementary to a gene expressed in heart tissue; useful for diagnosis of disease.

Assignee(s)

Colussi PA;

Taron $\mathrm{CH}$;

New England

Biolabs (Ipswich, MA, USA)

Pfeffer S: Tuschl TH

Pfeffer S, Tuschl TH

$8 / 24 / 2004$

$10 / 6 / 2005$

Fujita J

Fujita J

$3 / 23 / 2004$

9/29/2005

$\begin{array}{ll}\text { Affymetrix } & \text { Blume JE, } \\ \text { (Santa Clara, CA, Williams A }\end{array}$

USA)

Bridge JA,

Hinrichs SH,

Olsan RJ

Bridge JA,

Hinrichs SH,

Yissum Research Olsan RJ

Development Co.

Smith $Y$

$3 / 11 / 2004$

9/22/2005

of the Hebrew

Univ. of Jerusalem

(Israel)

Weng $\mathrm{L}$

Weng $\mathrm{L}$

$3 / 12 / 2004$

9/15/2005

Toyobo KK

Ishida Y,

$3 / 4 / 2004$

9/15/2005

(Tokyo)

Komatsubara

S, Oka M,

Segawa M

Yeda Research Domany E,

and Development Tsafrir D,

Co. Ltd.

Tsafrir I

(Rehovot, Israel)

Veridex

Wang $Y$

$12 / 8 / 2004$

9/9/2005

(Warren, NJ, USA)

ChondroGene

Liew C

$1 / 6 / 1999$

$9 / 8 / 2005$

(Toronto, ON,

Canada)

plate and a first spacer plate, an anode, a cathode, a voltage generator and a detector; useful for monitoring gene expression in single cells.

Source: Thomson Scientific Search Service (formerly Derwent). The status of each application is slightly different from country to country. For further details, contact Thomson Scientific, 1725 Duke Street, Suite 250, Alexandria, Virginia 22314, USA. Tel: 1 (800) DERWENT (http://www.thomson.com/scientific) 